\title{
IDENTIFIKASI Staphylococcus aureus DAN HITUNG TOTAL JUMLAH KUMAN PADA BAKPIA KACANG HIJAU
}

\author{
Richa Dwi Lestari $^{1)}$, Evy Ratnasari Ekawati ${ }^{2)}$, Imam Suryanto ${ }^{3)}$ \\ ${ }^{1)}$ Mahasiswa Teknologi Laboratorium Medik, FIKes, UMAHA \\ 2) Fakultas Ilmu Kesehatan UMAHA \\ 3)-Fakultas Ilmu Kesehatan UMAHa \\ E-mail: evysains@gmail.com
}

\begin{abstract}
ABSTRAK
Kue bakpia merupakan kue tradisional yang dikenal di beberapa daerah di Indonesia. Kue bakpia terbuat dari bahan-bahan seperti terigu, minyak sayur, gula halus, air dan garam. Isian dari kue bakpia ini umumnya adalah kacang hijau. Bakpia ada dua jenis, yaitu bakpia basah dan bakpia kering. Daya tahan dari bakpia basah dan bakpia kering berbeda. Bakpia basah bertahan sampai empat hari dan bakpia kering dapat bertahan hingga tiga minggu, terkadang juga kurang dari seharusnya. Tujuan dari penelitian ini untuk mengetahui adanya kontaminasi kuman Staphylococcus aureus dan menghitung jumlah total kuman dengan metode ALT pada kue bakpia basah. Hasil pemeriksaan identifikasi kuman Staphylococcus aureus terhadap 5 (lima) sampel bakpia kacang hijau basah didapatkan 2 (dua) sampel, yaitu sampel BP3 dan BP4 terkontaminasi Staphylococcus aureus. Sedangkan dari hasil hitung total jumlah kuman pada 5 (lima) kue bakpia kacang hijau basah belum memenuhi Standart Nasional Indonesia (SNI 7388:2009) tentang pangan, khususnya bakpia kacang hijau dengan batas maksimum cemarannya adalah 1 x $10^{4} \mathrm{cfu} / \mathrm{g}$ sampel.
\end{abstract}

Keywords : Bakpia kacang hijau basah, Staphylococcus aureus, Hitung Jumlah Total Kuman

\section{PENDAHULUAN}

Bakpia merupakan makanan yang terbuat dari campuran kacang hijau dan gula yang dibungkus dengan tepung dan kemudian dipanggang. Perkembangan bakpia sebagai komoditi dagang di industri makanan dan kuliner berkembang pesat di Yogyakarta. Perkembangan ini terjadi seiring dengan meningkatnya jumlah wisatawan yang berlibur ke kota Yogyakarta, sehingga industri bakpia sebagai industri kuliner berkembang mengikuti permintaan konsumen yang juga semakin meningkat (Anonim, 2014)

Seiring berjalannya waktu penjual bakpia kacang hijau tidak hanya ada di Yogyakarta, tetapi di Jawa Timur sudah banyak para produsen yang memproduksi bakpia, salah satunya di pasar Krian. Banyak masyarakat yang mengkonsumsi bakpia tidak menyadari makanan yang di konsumsi mengandung mikroorganisme pencemar yang harus diwaspadai, karena keberadaannya di dalam makanan sering tidak disadari, sehingga menimbulkan akibat-akibat yang tidak diinginkan, misalnya kerusakan makanan atau keracunan makanan (Kesmas, 2017).

Asal sumber mikroorganisme dalam pangan dapat berasal dari buah, sayuran, hewan, udara, tanah, limbah, air, manusia dan bahan tambahan pangan seperti tepung dan biji-bijian. Tepung dan biji-bijian dapat mengandung bakteri pathogen seperti Salmonella, Clostridium perfringens dan Staphylococcus aureus (Wardah, 2013).

Staphylococcus aureus dianggap sebagai satu-satunya pathogen dari genusnya. Staphylococcus aureus ditemukan pada $40 \%$ orang sehat dibagian hidung, kulit, ketiak atau perineum. Pathogen ini memproduksi koagulase yang 
mengkatalisis perubahan fibrinogen menjadi fibrin dan dapat membantu organisme ini untuk membentuk koloni yang kuat. Selain itu pathogen ini memproduksi enzim litik ekstraseluler (misalnya lipase) yang dapat memecah jaringan inang dan membantu invasi. Beberapa strain juga memproduksi eksotoksin poten yang dapat menyebabkan sindrom syok toksik. Enterotoksin yang diproduksi juga dapat menyebabkan diare (Ekawati, 2016).

Jenis makanan yang dapat ditumbuhi Staphylococcus aureus seperti hasil olahan telur, makaroni, susu dan keju. Makanan yang telah dimasak tersebut masih mungkin mengalami kontaminasi, misalnya melalui tangan atau lingkungan selama penyimpanan sebelum dikonsumsi. Keracunan Staphylococcus hampir selalu berasal dari makanan yang dimasak, karena pada makanan yang telah dimasak jumlah mikroba lain yang dapat menghambat pertumbuhannya sudah sangat berkurang (Kuswiyanto, 2015).

Menurut Saparinto dan Hidayati (2006), bahan makanan pada umumnya merupakan medium yang sesuai bagi pertumbuhan dan perkembangan mikroorganisme. Mikroorganisme dapat mengkontaminasi makanan oleh beberapa sebab, yaitu terbawa dari bahan makanan pada waktu proses produksi atau pada waktu pendistribusian produk, jenis makanan atau minuman yang disajikan dalam keadaan dingin, memiliki kandungan mikrobia yang buruk dibanding dengan penyajian dalam keadaan panas.

Berdasarkan permasalahn tersebut di atas, penulis melakukan identifikasi Staphylococcus aureus dan hitung jumlah total kuman pada kue bakpia basah.

\section{METODOLOGI PENELITIAN}

Metode yang digunakan dalam penelitian ini adalah merode eksperimen. Sampel penelitian adalah bakpia kacang hijau basah. Penelitian dilakukan di laboratorium Mikrobiologi FIKes UMAHA pada bulan Maret 2018.

\section{Peralatan Penelitian}

Erlenmeyer, beaker glass, cawan petri, pipet ukur, aluminium foil, karet, kapas berlemak, tabung reaksi, rak tabung, incubator, gelas ukur, hot plate, ose, lampu spiritus, timbangan digital, mikroskop, autoclave.

\section{Bahan Penelitian}

Bakpia kacang hijau basah, buffer phospat $\mathrm{pH}$ 7.2 $\pm 0.2, \mathrm{NA}, \mathrm{BAP}, \mathrm{NaCl}$ broth, MSA, NAS, Serum, PZ

\section{Prosedur Penelitian \\ Pengumpulan Sampel}

Bakpia kacang hijau basah diambil secara acak dari pasar Krian sebanyak 5 (lima) sampel dari beberapa penjual.

\section{Identifikasi Bakteri Staphylococcus aureus}

$25 \mathrm{~g}$ sampel dimasukkan kedalam Erlenmeyer yang berisi $225 \mathrm{~mL} \mathrm{NaCl}$ broth kemudian diinkubasi $37^{\circ} \mathrm{C} 24$ jam. Selanjutnya ditanam pada BAP, MSA, NAS dan diinkubasi $37^{\circ} \mathrm{C} 24$ jam. Koloni yang tumbuh pada BAP dilakukan pengecatan Gram, pada MSA diamati terkait fermentasi manitolnya, dan pada NAS digunakan untuk uji katale dan koagulase.

\section{Uji Katalase}

1 tetes PZ diteteskan pada objek glass ditambah dengan 1 mata ose biakan murni kuman dari NAS kemudian ditambah dengan 1-2 tetes $\mathrm{H}_{2} \mathrm{O}_{2} 3 \%$. Hasil positif ditandai dengan terjadinya gelembung gas.

\section{Uji Koagulase}

1 tetes serum/plasma citrate diteteskan di atas obyek glas ditmabha dengan 1 mata ose koloni kuman yang diambil dari NAS. Hasil positif ditandai dengan terjadinya penjendalan.

\section{Pengecatan Gram}

Koloni yang tumbuh pada BAP dibuat preparat. Selanjutnya preparat yang sudah difiksasi digenangi dengan gentian violet 3-5 menit, dicuci dengan air mengalir. Kemudian preparat digenangi lugol selama 1 menit, cuci kembali dengan aie mengalir. Langkah selanjutnya dilunturkan dengan menggunakan asetil alcohol 96\% selama 10 detik, cuci kembali dengan air mengalir. Langkah terakhir, preparat digenangi fuchsin 2-3 menit, dicuci kembali dan dikeringkan (Ekawati, 2015). 


\section{Hitung Jumlah Total Kuman metode ALT}

$25 \mathrm{~g}$ sampel yang telah dihancurkan kemudian dicampur dengan $225 \mathrm{~mL}$ buffer phosphate untuk mendapatkan pengenceran $10^{1}$. Suspensi sampel tersebut diencerkan hingga pengencera $10^{3}$. Sampel suspensi diambil $1 \mathrm{~mL}$ dengan menggunakan pipet. Masing-masing pengenceran dimasukkan kedalam cawan petri. PCA sebanyak $15 \mathrm{~mL}$ ditambahkan kedalam masing-masing cawan dan diinkubasi pada $37^{\circ} \mathrm{C}$ selama 24-48 jam (Ekawati, 2017).

\section{Pasca Analitik}

Diamati hasil pada identifikasi kuman dan dihitung hasil hitung jumlah total kuman pada tiaptiap pengenceran plate yang jumlah koloninya antara 25-250 (SNI, 2009).

\section{HASIL DAN PEMBAHASAN}

Hasil penelitian identifikasi dan hitung total jumlah kuman pada bakpia kacang hijau basah disajikan pada Tabel 1.

Tabel 1 Hasil Identifikasi Staphylococcus aureus dan Hitung Total Jumlah Kuman pada Bakpia

Kacang Hijau Basah

\begin{tabular}{|c|c|c|}
\hline $\begin{array}{c}\text { Kode } \\
\text { Sampel }\end{array}$ & $\begin{array}{c}\text { Hasil } \\
\text { Identifikasi }\end{array}$ & $\begin{array}{c}\text { Hitung Jumlah } \\
\text { Total Kuman } \\
\text { (cfu/g sampel) }\end{array}$ \\
\hline BP1 & $(-)$ & $2.5 \times 10^{5}$ \\
\hline BP2 & $(-)$ & $>250$ \\
\hline BP3 & $(+)$ & $>250$ \\
\hline BP4 & $(+)$ & $2.3 \times 10^{3}$ \\
\hline BP5 & $(-)$ & $>250$ \\
\hline \multicolumn{2}{|c|}{ Keterangan: (+) : adanya kontaminasi Stapylococcus aureus }
\end{tabular}

Dari tabel di atas dapat diketahui bahwa pada pemeriksaan identifikasi pada 5 (lima) sampel bakpia kacang hijau basah ditemukan 2 (dua) sampel terkontaminasi kuman Staphylococcus aureus, yaitu pada sampel dengan kode BP3 dan BP4.

Dari hasil pemeriksaan hitung jumlah total kuman pada tabel di atas diketahui bahwa pada sampel kode BP1 dan BP4 diperoleh jumlah total kuman secara berurutan sebanyhak $2.5 \times 10^{5} \mathrm{cfu} / \mathrm{g}$ sampel dan $2.3 \times 10^{3} \mathrm{cfu} / \mathrm{g}$ sampel. Pada sampel kode BP2, BP3 dan BP5 diperoleh jumlah total kuman sebanyak >250 $\mathrm{cfu} / \mathrm{g}$ sampel, sehinggga pada ketiga sampel tersebut tidak memenuhi syarat untuk dilakukan hitung jumlah total kuman metode ALT.

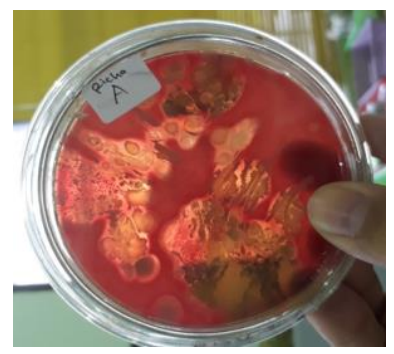

Gambar 1. Pertumbuhan Staphylococcus aureus pada BAP membentuk $\beta$-hemolisa

Dari 5 (lima) sampel bakpia kacang hijau, semuanya belum memenuhi Standart Nasional Indonesia (SNI 7388:2009) tentang pangan khususnya bakpia kacang hijau dengan batas maksimal cemarannya adalah 1 x $10^{4} \mathrm{cfu} / \mathrm{g}$ sampel.

Sampel yang terkontaminasi Staphylococcus aureus disebabkan karena udara, debu, air, pangan, peralatan makan, lingkungan, dan manusia. Bakteri ini tumbuh dengan baik dalam pangan yang mengandung protein tinggi, gula tinggi dan garam (Ekawati, 2016). Manusia dan hewan adalah tempat pertumbuhan yang utama. Staphylococcus ada di saluran hidung dan kerongkongan serta pada kulit dan rambut pada 50 $\%$ atau lebih individu yang sehat. Risiko lebih tinggi terjadi pada mereka yang sering berhubungan dengan individu yang sakit. Walaupun pengolah pangan merupakan sumber pencemaran pangan yang utama, peralatan dan lingkungan dapat juga menjadi sumber pencemaran Staphylococcus aureus (SNI 7388, 2009).

Nilai ALT yang melampaui batas maksimum cemaran dapat disebabkan karena penyimpanan bakpia yang kurang baik dan proses pembungkusan yang kurang steril, sehingga bakteri dapat tumbuh dan berkembang. Menghitung banyaknya bakteri dalam suatu bahan (makanan, minuman, dll) dilakukan untuk mengetahui jumlah bakteri, maka dapat diketahui kualitas darisampel tersebut. Sampel yang dapat dikatakan baik dan layak 
dikonsumsi, jika jumlah bakteri yang terkandung dalam sampel tersebut tidak melampaui batas maksimum (BPOM, 2009)

Menurut Peraturan Pemerintah No. 28 tahun 2004 tentang Keamanan, Mutu dan Gizi Pangan yang beredar tidak boleh mengandung atau melebihi batas maksimum cemaran mikroba yang ditetapkan dalam standar. setiap orang yang terlibat dalam rantai pangan wajib mengendalikan risiko bahaya pada pangan, baik yang berasal dari bahan, peralatan, sarana produksi, maupun dari perseorangan agar terjamin keamanan pangan. Peyelenggaraan kegiatan atau proses produksi, penyimpanan, pengangkutan, dan/atau peredaran pangan wajib memenuhi persyaratan sanitasi dan menjamin keamanan pangan dan/atau keselamatan manusia.

Untuk mengurangi resiko cemaran pada bakteri Staphylococcus aureus, maka perlu memperhatikan penyimpanan, penyimpanan di refrigerator merupakan cara yang dilakukan untuk mencegah pertumnbuhan bakteri, penyimpanan dapat dilakukan pada suhu $4^{\circ} \mathrm{C}$ jika tidak langsung dikonsumsi, mencuci tangan sebelum makan, tidak menyiapkan makanan untuk orang lain jika kita memiliki luka infeksi kulit pada tangan, memiliki penyakit hidung, dan infeksi mata, jika membeli makanan harus memperhatikan kemasan produk (Hariyadi, 2009).

\section{KESIMPULAN}

Dari 5 (lima) sampel bakpia kacang hijau basah didapatkan 2 (dua) sampel, yaitu sampel BP3 dan BP4 terkontaminasi Staphylococcus aureus. Sedangkan dari hasil hitung total jumlah kuman pada 5 (lima) kue bakpia kacang hijau basah belum memenuhi Standart Nasional Indonesia (SNI 7388:2009) tentang pangan, khususnya bakpia kacang hijau yang batas maksimum cemarannya adalah $1 \times 10^{4} \mathrm{cfu} / \mathrm{g}$ sampel.

\section{UCAPAN TERIMAKASIH}

Penulis mengucapkan terimakasih kepada Ibu dan Bapak Pembimbing serta kepada seluruh asdos di Laboratorium Bakteriologi yang telah banyak membantu selama penelitian.

\section{DAFTAR PUSTAKA}

Anonim. 2014. Retrieved from http://erepo.unud.ac.id/9205/3/40c0de 5ba8904d9ff20088a9ca5d4cb.pdf. Diakses Mei 2018.

BPOM. 2009. Penetapan Batas Maksimum Cemaran Mikroba dan Kimia Dalam Makanan. BPOM No.HK.00.06.1.52.4011.

Kesmas.2017. Kontaminasi Makanan.Retrivied from Public Health Home: http://www.indonesianpublichealth.com/kon taminasi-makanan. Diakses 20 Januari 2018.

Wardah, T.S. 2013. Mikrobiologi Pangan [Teori dan Praktek]. ANDI. Yogyakarta.

Ekawati E.R. 2015. Buku Ajar Bakteriologi 1. Wade Group publisher. Ponorogo.

Ekawati E.R. 2016. Buku Ajar Bakteriologi 3. Surabaya.

Ekawati E.R. 2017. Detection of Salmonella sp., Vibrio sp. and Total Plate Count Bacteria on Blood Cockle (Anadara granosa). IOP Conf. Series: Earth and Environmental Science 102 (2018) 012086. doi: 10.1088/17551315/102/1/012086.

Hariyadi D.R. 2009. Mencegah Keracunan Makanan Siap Santap. Autism Care Indonesia (ACI) Berbasis PAUD Posyandu Se-Bandung Raya. http://www.eurekaindonesia.org/category/gi zi-dan-kesehatan. Diakses April 2018.

Kuswiyanto. 2015. Bakteriologi 1: Buku Ajar Analis Kesehatan. EGC. Jakarta.

Saparianto C. dan Hidayati. 2006. Bahan Tambahan Pangan. Kanisius. Yogyakarta.

SNI. 2009. Batas Maksimum Cemaran Mikroba Dalam Pangan. 13. SNI-7388-2009. Bogor. 